\title{
APRENDER A SER CHIC: A PATINAÇÃO EM CURITIBA (1879-1916) - UMA EXPERIÊNCIA MODERNA
}

\author{
LEONARDO DO COUTO GOMES ${ }^{1}$ \\ ORCID: http://orcid.org/0000-0002-8866-2054 \\ LETÍCIA CRISTINA LIMA MORAES ${ }^{2}$ \\ ORCID: http://orcid.org/0000-0001-9444-8735 \\ VICTOR ANDRADE DE MELO 3 \\ ORCID: http://orcid.org/0000-0002-1983-1475
}

\begin{abstract}
RESUMO: Este estudo tem por objetivo discutir as experiências com a patinação promovidas em Curitiba entre 1879 (data do anúncio da primeira iniciativa) e 1916 (ano em que sete espaços dedicados à diversão funcionaram simultaneamente). $\mathrm{O}$ intuito foi investigar sua dinâmica social, bem como os discursos de adesão a ideias de civilização e progresso que se forjaram ao seu redor, posicionamentos que apresentaram indicações de adequados usos do corpo e de adoção de bons comportamentos públicos. Basicamente, interessa responder: a) como se estruturou a prática (estratégias de oferta, responsáveis, locais, frequentadores)? b) que representações sobre ela foram veiculadas? Como fontes, foram utilizados jornais e revistas publicados na cidade no período em tela. Conclui-se que a patinação foi mobilizada como uma possibilidade de educação do público no que tange à aquisição de posturas chics, uma noção ligada a concepções de modernidade que circularam com maior intensidade na capital paranaense no momento abordado.
\end{abstract}

Palavras-chave: História da Educação, História do Lazer, História do Esporte, Patinação, Curitiba.

\section{LEARNING TO BE CHIC: SKATING IN CURITIBA (1879-1916) - A MODERN EXPERIENCE}

\begin{abstract}
This study aims to discuss skating experiences promoted in Curitiba between 1879 (announcement of the first initiative) and 1916 (when seven skating places worked simultaneously). The objective was to investigate its social dynamics, as well as the discourses of adherence to ideas of civilization and progress forged around it, positions that presented indications of adequate uses of the body and the adoption of good public behaviors. Our main questions are: a) how was the practice structured (offering strategies, organizers, locals, frequenters)? b) what representations were conveyed

\footnotetext{
${ }^{1}$ Universidade Federal do Rio de Janeiro (UFRJ). Rio de Janeiro, RJ, Brasil. <leo_gomes.97@hotmail.com>

${ }^{2}$ Universidade Federal do Paraná (UFPR). Curitiba, PR, Brasil. <letsmoraes96@gmail.com>

${ }^{3}$ Universidade Federal do Rio de Janeiro (UFRJ). Rio de Janeiro, RJ, Brasil. <victor.a.melo@uol.com.br> Educação em Revista|Belo Horizonte|v.36|e235386|2020
} 
about it? The research sources were newspapers and magazines published in the city during that period. We conclude that skating was seen as a possibility of educating the public regarding the acquisition of chic postures, a notion linked to concepts of modernity that circulated with more intensely in the capital of Paraná at the time.

Keywords: History of Education, Leisure History, Sport History, Skating, Curitiba.

\section{APRENDER A SER CHIC: PATINAJE EN CURITIBA (1879-1916) - UNA EXPERIENCIA MODERNA}

RESÚMEN: Este estudio tiene el objetivo de discutir las experiencias con el patinaje promovidas en Curitiba entre 1879 (fecha del anuncio de la primera iniciativa) y 1916 (año en el que siete espacios dedicados a la diversión estaban simultáneamente abiertos). La intención es investigar su dinámica social, así como los discursos de adhesión a ideas de civilización y progreso que se forjaron a su alrededor, posiciones que presentaban indicaciones de usos adecuados del cuerpo y de la adopción de buenas conductas públicas. Básicamente, se intenta contestar: a) ¿cómo se estructuró la práctica (estrategias de oferta, responsables, locales, frecuentadores)?; b) ¿qué representaciones a este respecto se vehicularon? Como fuentes, utilizaron periódicos publicados en la ciudad en el período en cuestión. Se concluye que el patinaje ha sido movilizado como una posibilidad de educar al público para adquisición de posturas chics, una noción vinculada a conceptos de modernidad que circulaban con mayor intensidad en la capital de Paraná en el momento investigado.

Palabras clave: Historia de la Educación, Historia del Ocio, Historia del Deporte, Patinaje, Curitiba. 


\section{INTRODUÇÃO}

$\mathrm{Na}$ Inglaterra do século XVIII, a melhor configuração de uma estrutura pública de entretenimentos teve forte relação com o notável desenvolvimento mercantil, uma decorrência da Revolução Industrial que, por sua vez, foi indutora de processos de urbanização e estratificação social. As diversões se tornaram uma celebração das cidades que cresciam e um palco onde os diferentes grupos socioeconômicos, com destaque aos estratos médios, se apresentavam na cena urbana, simultaneamente demarcando hierarquias e forjando identidades diversas (classe, gênero, laborais, entre outras) (PORTER, 2001; SOARES, 2007).

Nesse cenário, no qual a articulação entre as noções de consumo e espetáculo ganharam centralidade na estruturação social, desencadearam-se preocupações no que tange aos comportamentos urbanos, até mesmo porque o "processo de comercialização do lazer e emergência de espaços públicos de diversão" foi, em parte, conduzido "por novos atores sociais que se pretendiam 'ilustrados' e "polidos"' (SOARES, 2007, p. 140).

Os entretenimentos ganharam, assim, uma relevância para além do divertir-se gratuitamente. Além de fontes de negócios, tornaram-se fóruns de educação com base em uma dupla dimensão: devese aprender a se portar no âmbito dos divertimentos e por meio desses adquirir comportamentos que devem ser generalizados.

Trata-se de uma dinâmica social ambígua, na qual excitabilidade e controle se articulam de maneira tensa. Os divertimentos, assim, constituem-se de uma importante experiência no diz respeito aos processos de adesão, ao ideário e imaginário da modernidade e à materialização no cotidiano de noções como civilização e progresso (MELO, 2019; MELO, 2020). Estamos de acordo com o que infere Silva (2009, p. 17):

(...) apontar para as potenciais contribuições que a visibilidade ocasionada pela esfera pública poderia trazer para o projeto de difusão de atitudes modernas pela população implica atentar para um aspecto primordial: um arranjo circunstancial de acontecimentos cotidianos que, de algum modo, se encarregaria de distribuir os enredos, atribuir e delimitar a importância de cada papel aos habitantes.

O novo modus vivendi impactou fortemente as experiências corporais, não somente porque a excitabilidade pública trouxe novas dimensões a serem aprendidas no que se refere ao sensório, como também porque comportamentos comedidos deveriam ser adotados. Como bem sugere Gunning (2001, p. 40):

Em todos esses novos sistemas de circulação, delineia-se o drama da modernidade: um colapso das experiências anteriores de espaço e tempo por meio da velocidade; uma extensão do poder e da produtividade do corpo humano e a consequente transformação deste por meio de novos limiares de demanda e perigo, criando novas formas de disciplina e regulação corporais com base em uma nova observação (e conhecimento) do corpo.

Se tais mudanças foram, a princípio, ocorrências tipicamente inglesas, com o decorrer do tempo passaram a ser britânicas, europeias e mundiais, um processo de trânsito cultural potencializado pelo desenvolvimento de um comércio internacional progressivamente sincronizado em função do aperfeiçoamento dos meios de transporte e de comunicação.

Ainda que se trate, em grande medida, de uma relação centro-periferia, não devemos tratar essa ideia como aquisição acrítica de valores e comportamentos. Nas mais diversas localidades, houve ressignificações devido à apreensão ativa dos receptores, bem como aos próprios limites contextuais ${ }^{4}$.

A questão passa a ser, portanto, entender os arranjos culturais específicos, as apreensões locais, saberes que são frutos de múltiplos diálogos e influências. Trata-se de tentar entender as

\footnotetext{
${ }^{4}$ Para um debate sobre trânsitos culturais e o estabelecimento não linear de uma relação centro-periferia, ver Canclini (1997) e Maia (2019).
} 
peculiaridades dos processos de adesão ao ideário e imaginário moderno. Uma chave de investigação é se debruçar sobre novas práticas que foram delineadas nesse cenário.

Esse é o caso da patinação, prática que, como meio de transporte e diversão, existe desde a Idade Média, mas que nos séculos XVIII e XIX ganhou uma nova conformação em função da invenção dos patins com rodas (antes havia somente os apropriados ao gelo) (BRANDÃO, 2009; MELO, 2017).

O novo artefato, e consequentemente a prática ao seu redor, tem forte relação com o desenvolvimento industrial, bem como com a valorização dos entretenimentos públicos e da permissibilidade de maior exposição corporal (CRARY, 2001). A patinação tornou-se reconhecida como possibilidade de experimentar sensações como velocidade, excitação, insegurança e risco, noções em voga no novo cenário social.

Para além disso, inclusive em função das vestimentas e do ambiente, a patinação foi entendida como território do chic-palavra em francês usada para designar o que era elegante e refinado -, uma experiência moderna para a qual os indivíduos teriam que ser educados com o objetivo de bem usufruir: no que tange a novas técnicas corporais, para que não caíssem; no tocante a comportamentos, para que se exponenciasse seu caráter civilizado.

$\mathrm{Na}$ segunda metade do século XIX, a patinação em rodas se espraiou para vários países, inclusive para alguns que não conheciam a modalidade anterior em função do clima, como é o caso do Brasil. Sobre seu estabelecimento em terras tupiniquins, já há estudos sobre o Rio de Janeiro (MELO, 2017; MELO, 2018), Porto Alegre (MELO; KARLS, 2016) e São Paulo (MELO; SANTOS, 2017). Como, então, teria se estruturado a prática em Curitiba?

Até meados do século XIX, Curitiba era eminentemente agrária, sendo sua zona urbana constituída basicamente por pequenos comércios varejistas, artesãos e uma modesta burocracia (PEREIRA, 1996). Seu desenvolvimento deveu-se à exploração comercial e à exportação sob modelos industriais da erva mate, acentuando-se por a cidade ter se tornado, em 1854, a capital da Província do Paraná (ZATTT, 2010).

Com isso, a população foi mudando seus hábitos, adequando-os a uma nova estrutura urbana que aspirava parâmetros de civilização e progresso, passando a exigir ruas pavimentadas, saneamento, iluminação noturna, lugares para diversão, conjunto de solicitações que também faziam parte das preocupações estatais, a busca de forjar a condição de capitalidade de Curitiba (PEREIRA, 1996). Esse processo se intensificou nas primeiras décadas do século XX, observando-se um ritmo mais acelerado de inovações e metamorfoses citadinas (GRUNER, 2012). Nesse cenário, foi se ampliando a dinâmica da vida pública, inclusive em função da melhor estruturação de um mercado de entretenimentos ${ }^{5}$.

Tendo em vista esse debate inicial, o objetivo deste estudo é discutir as experiências com a patinação promovidas na cidade de Curitiba entre 1879 (data do anúncio da primeira iniciativa) e 1916 (ano em que sete espaços dedicados à diversão funcionaram simultaneamente). O intuito foi investigar sua dinâmica social, bem como os discursos de adesão a ideias de civilização e progresso que se forjaram ao seu redor, posicionamentos que apresentaram indicações de adequados usos do corpo e de adoção de bons comportamentos públicos. Basicamente, interessa responder: a) como se estruturou a prática (estratégias de oferta, responsáveis, locais, frequentadores)? b) que representações sobre ela foram veiculadas?

Para alcance do objetivo, como fontes foram utilizados jornais e revistas publicados em Curitiba no período em tela. Na escolha desse material, levou-se em conta dois aspectos: a) ajuda a entender a repercussão da patinação, pois, no momento investigado, a imprensa já se constituía em um importante fórum público (MYSKIW, 2008); b) não foram encontrados outros documentos sobre a estruturação da prática na capital paranaense.

Os periódicos consultados apresentaram limites que devem ser assumidos. Poucos foram os posicionamentos de cronistas sobre a patinação. A maior parte das informações são anúncios e breves

\footnotetext{
${ }^{5}$ Para um debate sobre essa transição do rural para o urbano, em Curitiba, com base na adesão à ideia de progresso, ver Santos (1998).
} 
relatos sobre as experiências com a prática. De toda forma, procurou-se prospectar esses indícios com base no que sugere Luca (2005), sempre considerando a materialidade do veículo e da emissão ${ }^{6}$.

Dois desdobramentos nos estimularam à realização deste estudo: a) se desejarmos melhor entender como se deu o processo de educação para a experiência moderna, um bom caminho é investigar as práticas cotidianas que foram mobilizadas como intervenções; b) se tivermos em conta que a apreensão dos ideais de modernidade foi peculiar e múltipla, entender as especificidades da estruturação dessas iniciativas nos ajuda a lançar um olhar original para a história.

Trata-se, portanto, de aspirar uma contribuição para a história da educação, dos divertimentos e da cidade.

\title{
PATINAÇÃO: UMA DIVERSÃO MODERNA
}

\author{
"SKATING-RINK. Brevemente começará nesta cidade este divertimento que tem tido grande aceitação e \\ causado admiração na Corte."
}

Com essas breves palavras, anunciou-se a chegada na capital paranaense de uma diversão que já atraia bom público em outras cidades brasileiras: a patinação. No Rio de Janeiro, as pioneiras experiências com a prática ocorreram em 1872, mas somente em 1878 tiveram seu primeiro momento de grande êxito, protagonizado por Frederico Glette e pelos irmãos Normanton que, em 1877, tinham inaugurado um rinque em São Paulo. Em Porto Alegre, o skating começou a ser praticado também em 1878. Em Curitiba, não conhece-se o responsável pela iniciativa. O que se pode perceber é que, em relação ao esporte dos patins, estava sintonizado com o que ocorria nas outras províncias.

A referência ao fato de que a patinação gozava de boa aceitação no Rio de Janeiro era uma estratégia de apresentação da novidade, uma forma de dizer à sociedade curitibana que se tratava de algo digno de ser experimentado. Certamente, para a maior parte da população, o uso dos patins se constituía de uma alternativa recreativa e singular, uma experiência corporal pouco usual numa cidade que dava seus primeiros passos de modernização.

Há poucas informações sobre essa primeira iniciativa. Provavelmente, tenha sido a mesma anunciada alguns meses depois tendo como sede o Salão Wendler ${ }^{8}$, um estabelecimento que acolhia muitos eventos sociais e que, em certa ocasião, foi definido como um "vasto salão (...) decorado com simplicidade e elegância" ". O proprietário possivelmente era João Christiano Wendler, alemão naturalizado, comerciante, dono de um botequim ${ }^{10}$ e um açougue ${ }^{11}$, importador de cervejas num momento em que ainda era mais usual o hábito de beber vinhos e licores.

\footnotetext{
${ }^{6}$ Neste artigo, não tratamos as imagens como fontes propriamente ditas, mas sim como ilustrações.

${ }^{7}$ SKATING-Rink. Dezenove de Dezembro, 2 jan. 1879, p. 4. Esse periódico circulou entre 1854 e 1890, o primeiro publicado na cidade, relacionado à necessidade de promover/consolidar Curitiba como capital da província (PEZZOLE, 2006). Em suas páginas, atos oficiais diversos dividiam espaço com notícias sobre o comércio, economia e dinâmica social.

8 Província do Paraná, 9 mar. 1879, p. 4. Esse periódico circulou entre 1876 e 1889. Ligado ao Partido Liberal, basicamente publicava notícias locais e ocorrências politicas (PILOTTO, 1976).

${ }_{9}$ Província do Paraná, 17 out. 1877, p. 4.

${ }^{10}$ Almanack da Província do Paraná, 1876, p. 116. Esse periódico circulou entre os anos de 1876 a 1880. Dedicava-se a discutir a economia da província e do país, bem como publicar processos administrativos.

11 Almanack da Província do Paraná, 1877, p. 107. 


\section{SKITING-RINK}

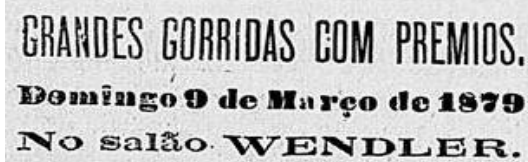

Entrada 500 reis, com direito a numa garrafa de cerveja.

\section{Viva a patinação !}

Anúncio da $1^{\mathrm{a}}$ experiência de patinação em Curitiba. Província do Paraná, 9 mar. 1879, p. 4.

Talvez isso explique porque, ao pagar a entrada do Skating-Rink, o frequentador ganhasse uma garrafa de cerveja. De fato, tendo em vista o desconhecimento público acerca da prática, o responsável procurou criar estímulos diversos. O bilhete custava 500 réis, valor menor do que nas outras capitais (1000 réis). O preço era atrativo. Basta ter em conta que o ticket mais barato de uma atração popular na Curitiba da época, o Circo Serino, custava $1 \$ 000^{12}$.

Devemos ter em conta que se tratava de uma cidade pequena, mesmo que já crescesse com alguma rapidez. Em 1872, tinha cerca de 12.000 habitantes, chegando a cerca de $24.000 \mathrm{em} 1890^{13}$. Era um reduzido mercado consumidor, um desafio para a viabilização das iniciativas do âmbito de entretenimento. Os empresários tinham que se esmerar para atrair interessados.

O estabelecimento tinha como endereço a Rua da Graciosa (atual Barão do Serro Azul), um logradouro que, a despeito de problemas sempre observados nos jornais, localizava-se numa das áreas melhor urbanizadas, o Centro, entre a Matriz e a Praça 19 de Dezembro, onde boa parte dos mais importantes acontecimentos da cidade tinham sítio.

Além disso, por lá se situavam, entre outros, comércios de moda e de novidades, como a Casa da Lua (de Affonso Stellfeld), a Tesouro da Moda (de João Leandro Rodrigues) e o armazém de Germano Liedermann. O Clube Curitibano, sociedade recreativa criada em 1881 pelos "mais estimáveis cavalheiros" ${ }^{\prime 14}$, também teve sua primeira sede nessa rua.

Essa região central foi valorizada durante décadas, local onde se instalaram os maiores empreendimentos de Curitiba, inclusive do âmbito do entretenimento. Não surpreende saber que quase todos os rinques de patinação do período que investigamos tenham se estabelecido nessa área da cidade.

\footnotetext{
12 Província do Paraná, 9 mar. 1879, p. 4.

${ }^{13}$ Disponível em: <https://censo2010.ibge.gov.br/sinopse/index.php?dados=6 >. Acesso em: 4 mar. 2020.

14 CLUBE Curitibano. Dezenove de Dezembro, 1 out. 1881, p. 3. 


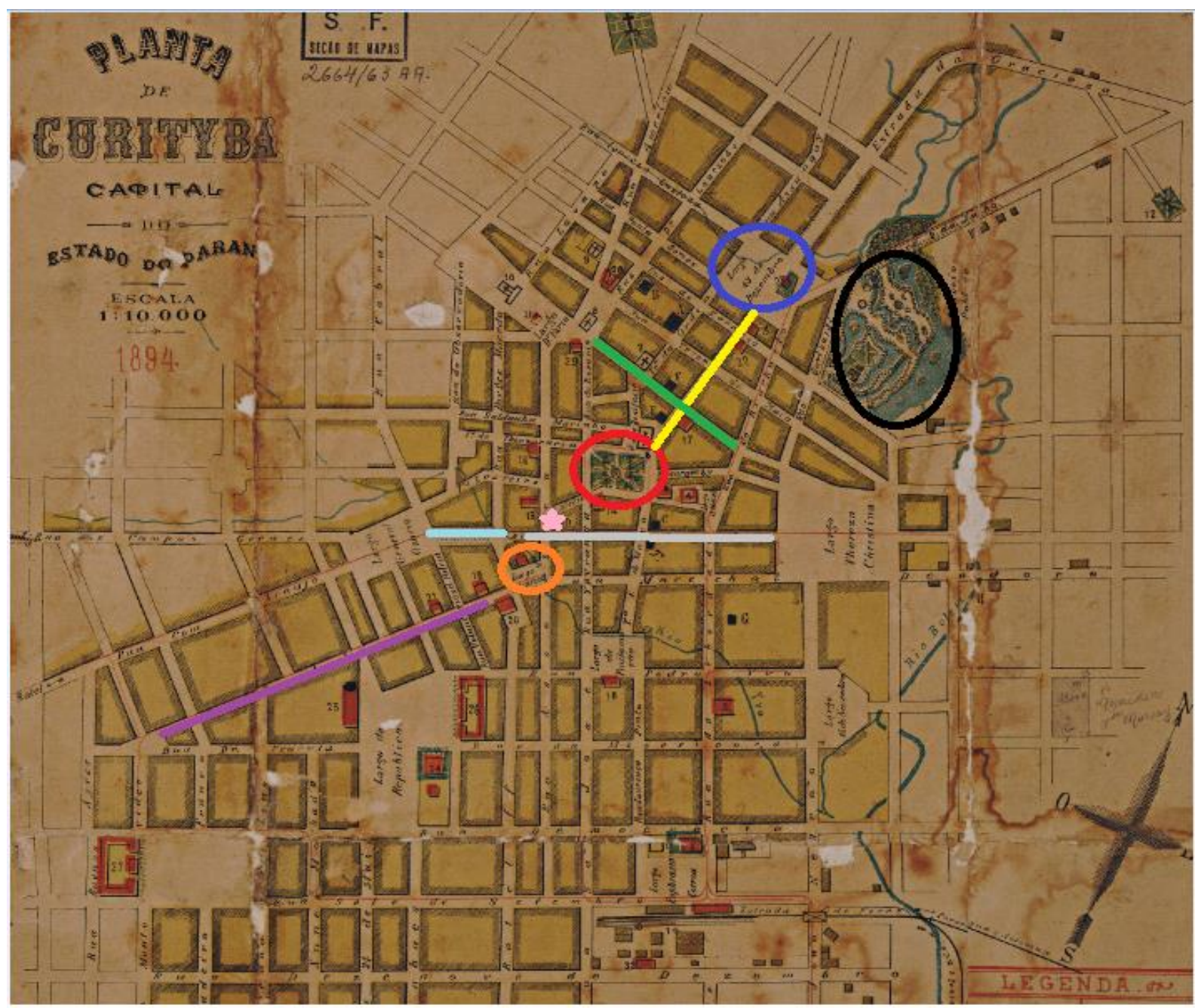

Planta de Curitiba, 1894.

Acervo do Arquivo Nacional.

Disponível em:

< https://pt.wikipedia.org/wiki/Hist $\%$ C3\%B3ria de Curitiba\#/media/Ficheiro:Mapa da cidade de Curitiba.tif $>$.

Logradouros onde houve iniciativas de patinação.

Em vermelho, o Largo da Matriz. Em azul escuro, a Praça 19 de Dezembro. Em preto, o Passeio Público. Em Laranja, a Praça Zacarias. Em amarelo, a Rua da Graciosa (atual Barão do Serro Azul). Em verde, Rua do Fogo (atual São Francisco).

Em lilás, Rua Aquidabã (atual Emiliano Perneta). Em rosa, esquina da Rua da Assembleia (atual Rua Dr. Muricy) e Rua Alegre (atual Dr. Cândido Leitão). Em azul claro, a região da atual Avenida Luiz Xavier (construída no início do século XX).

Em cinza, Rua 15 de Novembro.

Deve-se considerar que, àquela altura, a cidade já passara pelas reformas do Plano Taulois, implementado a partir de 1855 com o intuito de preparar Curitiba para assumir a condição de capital da província. Nesse cenário, "a elite emergente passou a introduzir novos hábitos de consumo e novas reivindicações sociais (...), como escolas, teatros, áreas de lazer, entre outros” (GALERA, 2014, p. 89). Nesse processo, importante foi a contribuição de europeus ${ }^{15}$, notadamente aqueles que se estabeleceram no perímetro urbano, caso dos alemães.

Estabelecimentos como os de Wendler apresentavam à cidade as novidades do campo do entretenimento. Não surpreende que outra experiência com a patinação, promovida em 1880, tenha ocorrido em espaço semelhante, no Café Restaurante Lindmann, localizado na Rua do Fogo (atual São Francisco). No anúncio da oferta da prática há que se destacar a informação de "reabertura do skating-

15 A maior presença de europeus no país teve relação com a Lei das Terras, que "facilitou a aquisição de terras por parte dos imigrantes que vieram ao Brasil para suprir a mão de obra escrava no campo" (GALERA, 2014, p. 90). 
rink" ${ }^{\prime 16}$. Em comum com a iniciativa anterior, o horário de funcionamento: domingos, fim de tarde e início da noite.

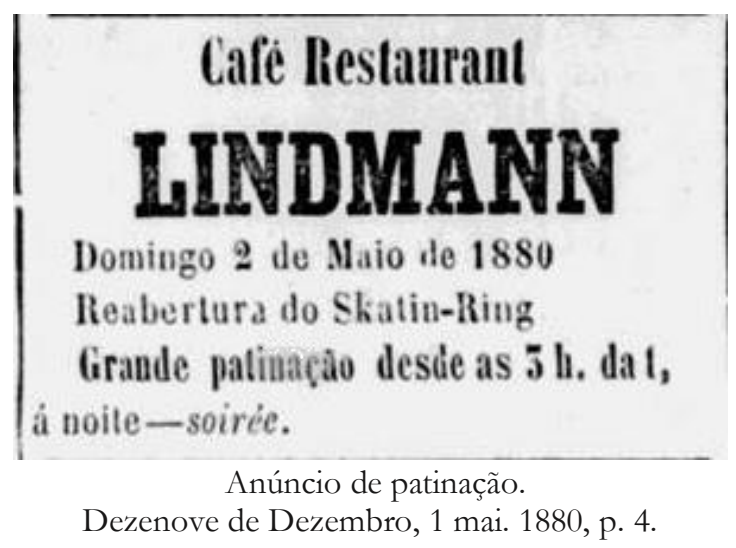

Não é difícil que o anúncio tenha feito uma referência à pioneira experiência curitibana com a patinação. A ser verdade essa hipótese, provavelmente havia um empresário responsável que fazia uso das instalações de estabelecimentos que tinham espaço, disposição para acolher novidades e algum reconhecimento social. Tendo em vista o que ocorreu em outras cidades, e o fato de que, em 1879 houve corridas, é possível que um plantel de patinadores contratados integrasse a iniciativa. Lamentavelmente, a escassez das informações não permite avançarmos nessas considerações, mas não parece imprudente reforçar a ideia de que a prática compunha a estrutura de entretenimentos públicos que se urdia na cidade.

No Salão Lindmann, por exemplo, usualmente eram programados concertos e eventos musicais ${ }^{17}$ num momento em que a cidade ainda não tinha um teatro adequado ${ }^{18}$. Por lá, também eram promovidos animados bailes ${ }^{19}$ e apresentações dramáticas ${ }^{20}$. Tal sua importância, foi o local escolhido para a fundação do já citado Clube Curitibano.

Vale citar que o proprietário, Adolfo Lindmann, era um personagem importante na cidade, uma das lideranças da colônia alemã. Comerciante e durante algum tempo responsável por uma empresa sanitária, envolveu-se com várias iniciativas de dinamização social, entre as quais a fundação da Sociedade Thalia (1882), destinada a promover reuniões de canto, leitura e conversas (COLATUSSO, 2004).

Depois dessas experiências de 1879 e 1880, durante uma década e meia não encontramos indícios concretos de que a patinação tenha sido oferecida por algum estabelecimento, ainda que não seja impossível que seguisse existindo de maneira espontânea, praticada por alguns curitibanos. Evidência relevante é sua presença, nos anos 1890, nas atividades do Colégio São José, utilizada como estratégia de educação física em conjunto à ginástica, ao tiro ao alvo e à esgrima.

A valorização dessas práticas corporais era um dos aspectos observados nos elogios à escola constantemente publicados nos periódicos curitibanos: "Podemos garantir que os melhoramentos introduzidos no Colégio S. José (...) fazem desse estabelecimento de instrução o mais importante de todos quantos possuímos no Estado, preparado como se acha para o ensino, sob pontos de vista da instrução popular"'21.

A patinação, inclusive, integrava a programação de uma das mais valorizadas atividades da escola: as festas de fim de ano, nas quais se procurava apresentar publicamente os bons resultados obtidos

\footnotetext{
${ }^{16}$ Dezenove de Dezembro, 1 mai. 1880, p. 4.

17 Ver: CONCERTO musical. Dezenove de Dezembro, 30 jul. 1881, p. 4.

${ }^{18}$ Havia o Teatro Curitiba, mas o primeiro de maior renome foi o Teatro São Theodoro, inaugurado em 1884, reinaugurado, depois de um tempo fechado em função da Revolução Federalista, em 1900, já com o nome de Guaíra (GILLER, 2013).

${ }^{19}$ HEIMAT. Dezenove de Dezembro, 14 ago. 1880, p. 4.

${ }^{20}$ Posteriormente, o Salão adotou o nome de Teatro Lindmann (GRUPO dos amadores. Dezenove de Dezembro, 17 jan. 1883, p. 4).

${ }^{21}$ COLÉGIO S. José. A República, 19 jun. 1895, p. 1. A República: Órgão do Partido Republicano (PR), editado entre 1886 e 1930, se tornou o jornal de maior circulação da capital paranaense. Em suas páginas, houve muitos debates sobre civilidade e progresso, em sintonia com os discursos republicanos candentes no Brasil de fim de século (CORRÊA, 2009). 
por meio de apresentações de naturezas diversas ${ }^{22}$. Nas palavras de um cronista, "um verdadeiro e edificante torneio de instrução e de educação física e moral" 23 .

É necessário considerar que, na década final do século XIX, algumas ocorrências interferiram no dinamismo da vida pública curitibana. Uma delas foram surtos epidêmicos em 1889 e 1891 (GALERA, 2014). Esses acabaram incentivando as reformas urbanas e incrementando as preocupações com a saúde e a higiene (BERTUCCI, 2011). Outra foi a Revolução Federalista (18931895 $)^{24}$. De toda forma, as principais mudanças da cidade, como vimos, foram implementadas mesmo nos anos iniciais do século XX, especialmente na década de 1910. Foi nesse momento que houve um primeiro ciclo mais constante de oferta da patinação na capital paranaense.

Em 1904, a patinação era uma das atividades oferecidas pelo Sport-Club, uma agremiação multiesportiva ${ }^{25}$ no mesmo ano criada, cujos sócios eram, segundo um cronista, uma "plêiade de moços de nossa mais fina sociedade", "nossas mais gentis damas e distintos cavalheiros" no antigo Frontão Curitibano, espaço de pelota basca localizado na Rua Aquidabã (atual Emiliano Perneta).

Na cerimônia de inauguração do clube, entre tantas atrações elogiadas, asseverou um cronista: "A patinação, porém, foi a magna atração da festa, distinguindo-se em exercícios cheios de dificuldade os srs. Chermont de Brito e alferes Mota Pacheco, dois sportmen completos neste gênero de diversão" ${ }^{27}$. Na ocasião, muitos se dedicaram à arte dos patins, um indício de que a prática tinha alguma circulação, mesmo que não tenhamos evidências concretas.

Um destaque importante é que com o skating se envolviam homens e mulheres ${ }^{28}$, um sinal da maior presença feminina na cena pública. Na verdade, no âmbito do Sport-Club, a patinação era, junto à dança, a prática corporal na qual mais havia tal participação.

Não era um caso isolado. Priori (2017) percebeu que a presença feminina nas ruas curitibanas aumentou muito no cenário em que a vida cultural e artística se modernizava. Segundo a autora, conforme cresceu o número de espaços públicos voltados aos divertimentos - cafés, salões de dança, praças, parques, cinemas, clubes e associações -, tornou-se progressivamente notável a participação de mulheres como consumidoras, público, praticantes, funcionárias e até mesmo empreendedoras. Trindade (1996, p. 129) também identificou tal quadro, sendo ainda mais assertiva:

O lazer é responsável por uma invasão feminina dos espaços da cidade. Trata-se de um novo domínio, oriundo em grande parte do desenvolvimento urbano, no qual a mulher que a sociedade conservadora oitocentista segregara nas dimensões do privado, retorna às ruas para nelas despender seu tempo livre nas lojas, nos parques, nas casas de espetáculos, nos campos de esportes, nos salões dos clubes recreativos.

Esse encontro de sexos mais amiúde na cena pública aumentou as preocupações no que tange ao pudor, enfatizando-se os discursos sobre a precisão de um processo de educação para a convivência adequada. De outro lado, para os que patinavam também se impunha a necessidade de aprendizado de técnicas corporais a fim de evitar acidentes que se tornaram mais comuns, especialmente as quedas que sempre eram motivo de comentários ${ }^{29}$.

\footnotetext{
22 Sobre essas festas escolares de fim de ano, ver Melo e Peres (2016).

23 COLÉGIO S. José. O Município, 2 jul. 1898, p. 1. Ligado aos interesses da Câmara Municipal, além de divulgar os acontecimentos da capital paranaense, esse periódico circulou um curto período de tempo (1897-1898) (O Município, 4 dez. 1897, p. 1).

24 Para mais informações, ver Sêga (2001) e Lacerda (2014).

${ }^{25}$ No clube, praticava-se o futebol, o jogo da pelota, a ginástica, o tiro ao alvo, a esgrima e a patinação.

26 SPORT-Club. A República, 28 nov. 1904, p. 2. Para mais informações sobre o clube, ver Moletta Júnior (2009).

27 SPORT-Club. A República, 28 nov. 1904, p. 2.

28 TEATROS e diversões. Diário da Tarde, 12 dez. 1904, p. 1-2. O Diário da Tarde (1899-1940) apresentava uma forte tendência liberal e anticlerical (BENVENUTTI, 2004; CAMPOS, 2013). Para além dos artigos de opinião, em suas páginas se encontravam notícias da economia, política e temas cotidianos.

${ }^{29}$ Ver, por exemplo: TEATROS e diversões. Diário da Tarde, 12 dez. 1904, p. 1-2.

Educação em Revista|Belo Horizonte|v.36|e235386|2020
} 
É digno de registro que a prática não estivesse mais somente no âmbito dos salões, nem tampouco das escolas, mas numa instituição que, de alguma forma, mesclava algo dos dois, o entretenimento com um sentido educacional mais explícito. A patinação, assim, fez parte do fluxo de desenvolvimento esportivo de Curitiba, que se deu pari passu com a melhor estruturação do mercado de diversões $^{30}$. Todavia, não era considerada como motivo de competições, mas sim como uma vivência cotidiana com a qual se divertiam homens e mulheres ${ }^{31}$.

Tendo em vista o perfil do clube, majoritariamente integrado pela elite curitibana, tratava-se de uma iniciativa mais restrita, acessível somente para sócios e convidados. Havia outras alternativas, contudo. Uma delas era um rinque instalado na Cervejaria Cruzeiro, localizada no bairro do Batel. Nesse caso, era apresentada também como um exercício físico, a "ginástica da patinação" 32 , mas encarada eminentemente como uma diversão.

Esse estabelecimento merece destaque. Era a mais antiga fábrica de cerveja da cidade (a Tivoli de João Leitner), renomeada para Cruzeiro em 1904. Assim como em outras cidades, ao seu redor foi instalado um parque no qual eram oferecidas atrações diversas, entre as quais a patinação ${ }^{33}$.

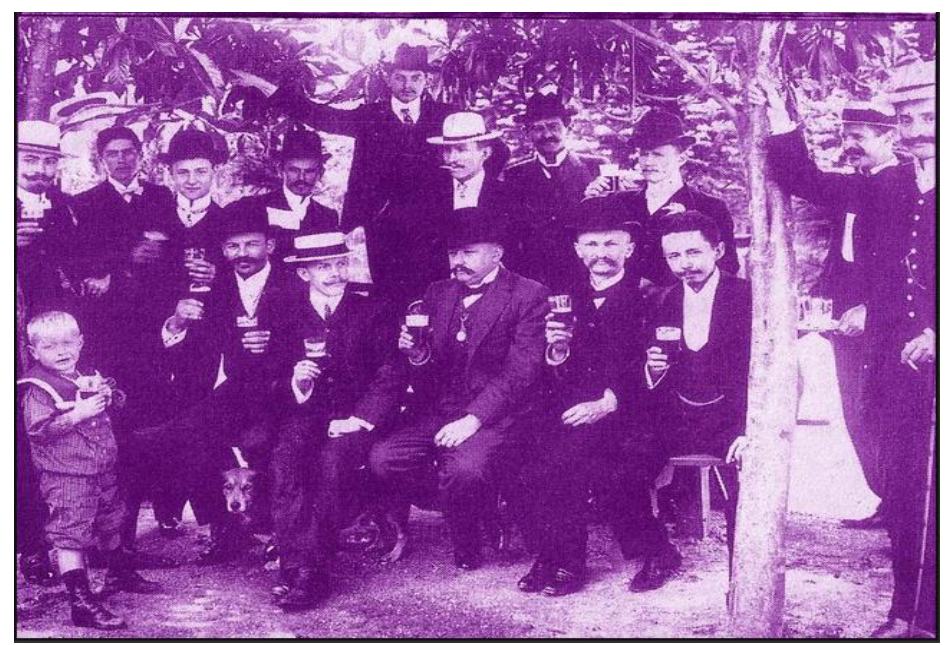

Parque da Cervejaria Cruzeiro, no Batel, 1905.

Disponível em: http://curitibanaquelesidos.blogspot.com/2015/01/parque-da-cervejaria-cruzeiro-no-batel.html.

O parque da Cervejaria Cruzeiro fazia parte de um conjunto de iniciativas entabuladas com base no processo de mudanças pelo qual passava a cidade:

Nas primeiras décadas do século XX Curitiba procurava se modernizar. (...). No centro da cidade os bondes puxados a cavalos passam a ser substituídos por modernos bondes elétricos e surgem os primeiros cinemas e teatros. Recuperou-se o Passeio Público e os frequentadores puderam usufruir o seu carrossel, as gôndolas para passeios no rio e o quiosque para botequim. No Batel, o Parque da Cervejaria Cruzeiro proporcionava à população espaço para o saudável hábito da ginástica. E no Coliseu Curitibano, um parque de diversão se abria aos prováveis usuários, congregando cinema, patinação, tiro ao alvo, bandas e um esplêndido serviço de botequins (VIACAVA, 2009, p. 3).

Como se pode ver, com perfil semelhante ao da Cervejaria Cruzeiro, havia o Coliseu Curitibano, inaugurado em 1905, na Rua Aquidabã (atual Emiliano Perneta). Era um complexo de entretenimentos onde diversões de todos os tipos eram oferecidas, entre as quais a patinação. À frente

\footnotetext{
30 Sobre a estruturação do esporte em Curitiba naquele período, ver Moraes e Silva (2011).

31 Tirando o caso da primeira experiência com a patinação (1879), só identificamos a promoção de corridas de patins em um estabelecimento que foge ao recorte deste estudo, o Rio Branco Rink, localizado na Rua Barão do Rio Branco, inaugurado em 1918 (RIO Branco Rink. Diário da Tarde, 10 mai. 1918, p. 2).

32 DIVERSAS. A República, 21 dez. 1904, p. 2.

${ }^{33}$ No bairro do Batel, também era oferecido um parque com atrações: a Cervejaria Providência. Para mais informações sobre o parque da Cervejaria Cruzeiro, ver Moraes e Silva (2011). Sobre as cervejarias como espaço de lazer, ver Melo e Karls (2018). Educação em Revista|Belo Horizonte|v.36|e235386|2020
} 
do negócio se encontravam dois nomes que já estavam há anos envolvidos com o ramo dos divertimentos em São Paulo e Curitiba (futuramente iriam também conquistar o Rio de Janeiro): Antonio Gadotti e Francisco Serrador (MORAES, 2012).

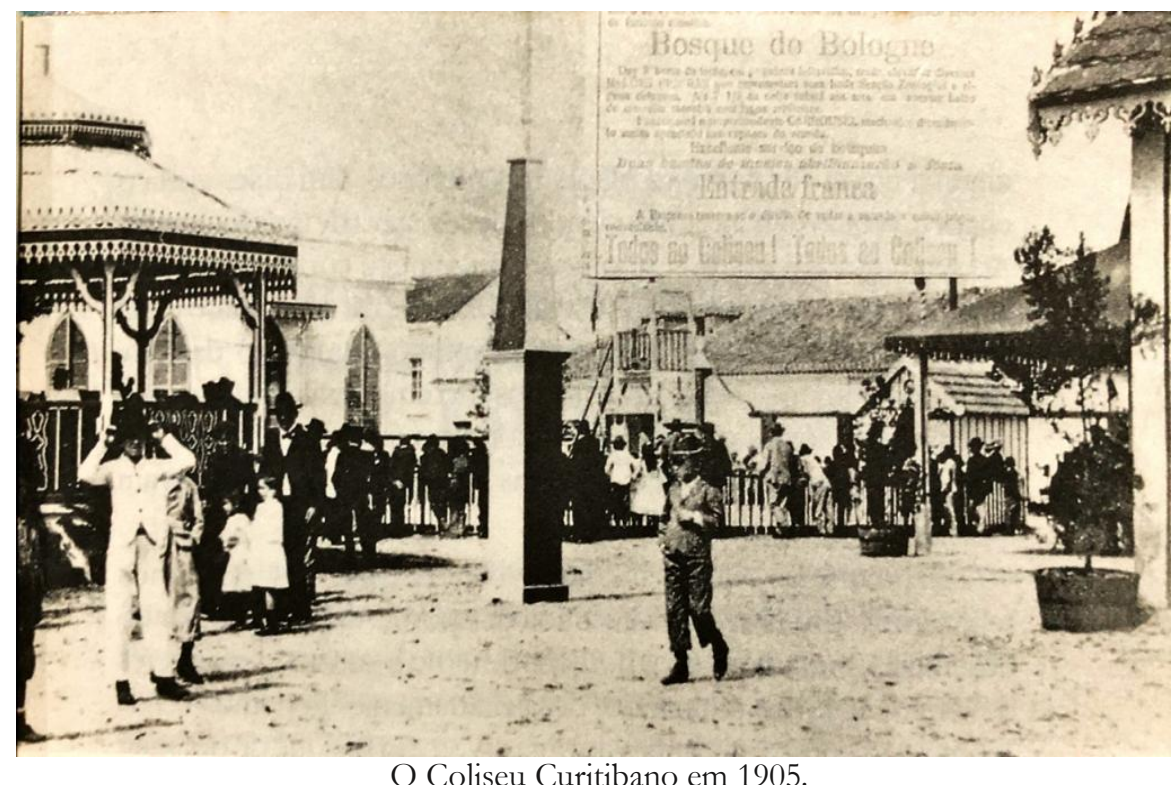

(BRANDÃO, 1994).

Nos anos iniciais do século XX, parques de diversão foram abertos em muitas cidades brasileiras, com destaque para as iniciativas dos irmãos Segreto na capital federal (MARTINS, 2004). Importantes espaços urbanos, contribuíram para a adequação dos indivíduos à dinâmica moderna, centros de educação informal que atraíam grande público à busca de entretenimento (SILVA, 2009; MELO, 2020). Em Curitiba não foi diferente, tornando-se referências relevantes já nos anos 1900 (GRUNER, 2012).

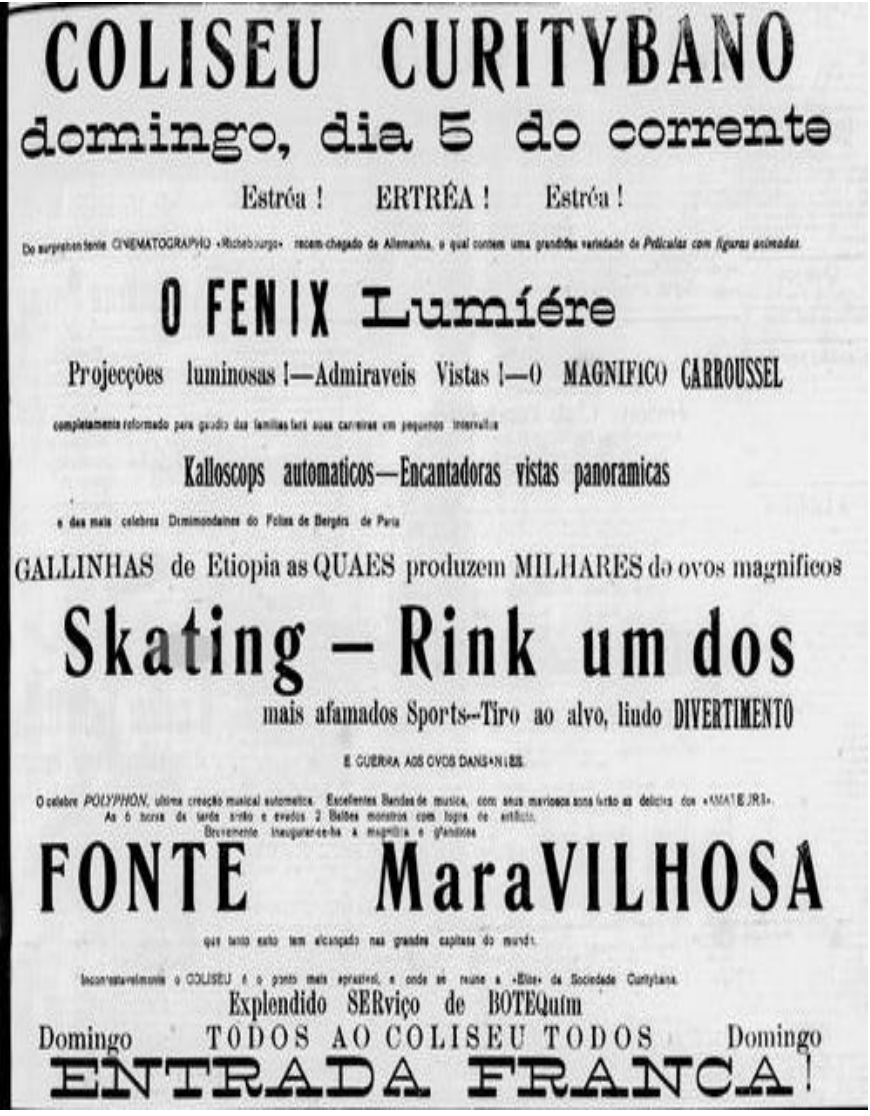

Educação em Revista|Belo Horizonte|v.36|e235386|2020 
No Coliseu, a patinação teve seu efetivo primeiro grande sucesso na capital paranaense, a reboque da intensa aceitabilidade que o estabelecimento logrou entre os curitibanos. Desde a inauguração, a prática obteve destaque, apresentada nos anúncios como "um dos mais afamados esportes" 34 , "um dos mais modernos esportes" ${ }^{35}$ ou "esporte da moda" 36 . Além disso, em função de uma pista construída "com todas as comodidades possíveis", inclusive iluminação elétrica, era possível patinar até pelas noites.

Mesmo que houvesse constrangimentos no que se refere a exigências nem sempre explícitas de roupas e comportamentos - nos anúncios se informava que a "Empresa se reserva o direito de vedar a entrada de quem julgar inconveniente" ${ }^{37}$-, o Coliseu acolhia maior diversidade de público, inclusive por ser de entrada franca ${ }^{38}$. Pagava-se por cada atração, além de comida e bebida.

Patinar custava 500 réis por hora. Esse valor era proporcional a outras diversões da cidade, como os soirées e as salas de bilhar (GOMES, 2019). Era um preço relativamente acessível para estratos médios e mesmo médios-baixos. Além disso, deve-se considerar que o Coliseu funcionava diariamente a partir das 17 horas $^{39}$, mas a pista de patinação ficava aberta de $8 \mathrm{~h}$ às $11 \mathrm{~h}, 13$ às $16 \mathrm{~h}$ e $17 \mathrm{~h}$ às $22 \mathrm{~h}^{40}$. Esses são indícios de que havia interessados de diversos grupos sociais.

Em 1906, depois que o Coliseu passou por uma reforma, a patinação ganhou ainda mais relevância. Uma fonte iluminada tornou a pista ainda mais bela e atrativa. Aumentou-se o número de patins disponíveis para aluguel. Mais ainda, começaram a ser oferecidas aulas da modalidade ${ }^{41}$, uma preocupação explícita com o ensino de técnicas corporais com o intuito de atrair mais público, exponenciando o sucesso já obtido.

\footnotetext{
${ }^{34}$ Diário da Tarde, 3 nov. 1905, p. 3.

35 A Notícia, 25 nov. 1905, p. 3. Esse periódico circulou entre 1905 e 1908. Dedicava grande atenção à vida social de Curitiba, especialmente aos divertimentos públicos.

36 Diário da Tarde, 22 nov. 1906, p. 2.

37 A Notícia, 6 nov. 1906, p. 3.

38 Posteriormente, passou-se a ser cobrado um pequeno valor de ingresso, 200 réis.

${ }^{39}$ Posteriormente, passou a funcionar de $5^{\mathrm{a}}$ a domingo.

40 Diário da Tarde, 17 mar. 1905 , p. 3.

41 A Notícia, 3 nov. 1906, p. 3.
} 


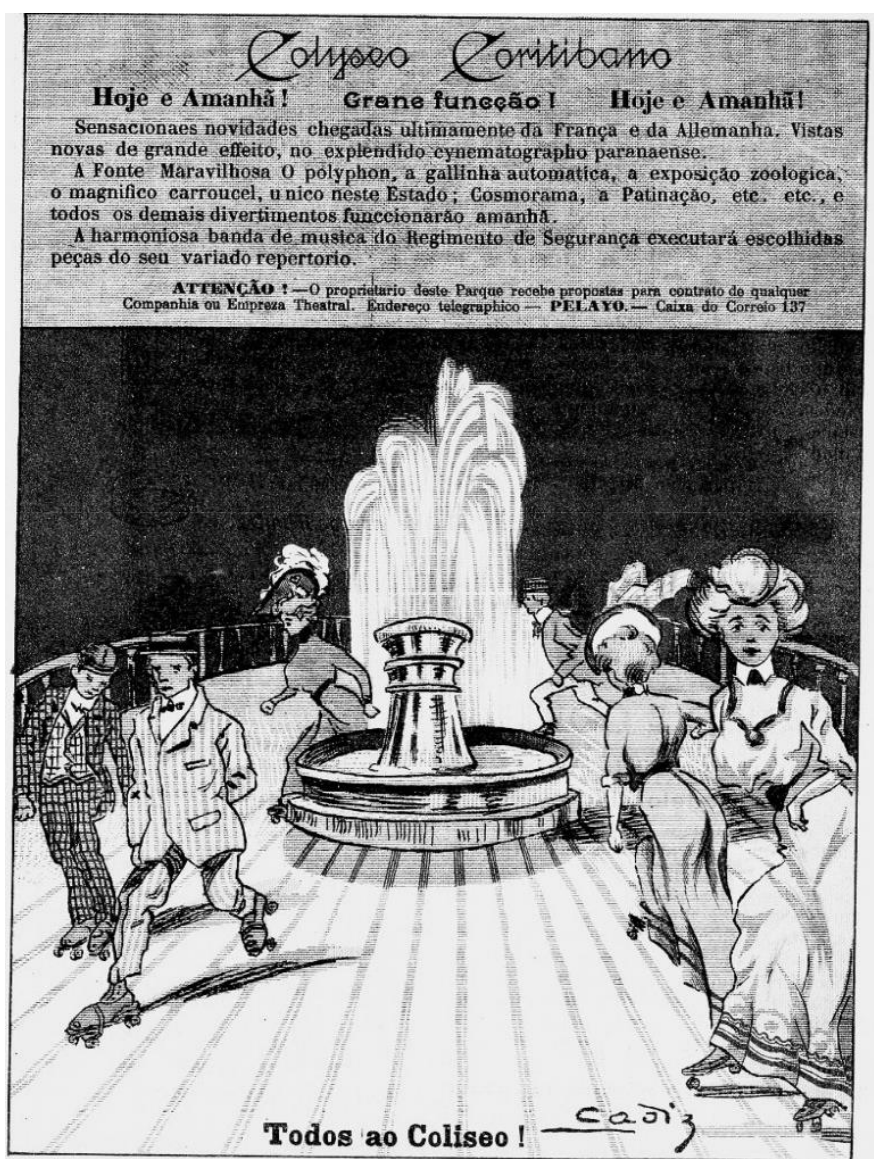

Anúncio do Coliseu. Gravura da pista de patinação com a fonte iluminada ao centro. Vale observar a distinção das roupas dos praticantes.

Revista Olho da Rua ${ }^{42}, 12$ out. 1907, p. 28.

Mesmo muito elogiado, havia também polêmicas que cercavam o Coliseu. Parte da manutenção do negócio devia-se a jogos de azar, que alguns consideravam incompatíveis com a prática da patinação ${ }^{43}$. Além disso, o aumento da frequência por gente de diferentes estratos criou tensões entre os frequentadores.

Há que se ter em conta que essas iniciativas do mercado do entretenimento conviviam com as do campo esportivo. O Sport-Club continuou a estimular a prática da patinação, outras agremiações fizeram o mesmo, como foi o caso do Clube Esportivo, saudado por ser uma expressão da compreensão da "necessidade inadiável do desenvolvimento físico, base única do desenvolvimento moral e intelectual" ${ }^{44}$. As ênfases discursivas na valorização do skating eram distintas nos dois âmbitos.

Essas diferenças se tornaram mais complexas na primeira metade da década de 1910, quando a patinação teve um crescimento exponencial em Curitiba, em grande parte graças a sua oferta em complexos de entretenimento, como o Polytheama, novo nome do antigo Coliseu Curitibano (VANALI, 2017).

Naquela altura, 1912, o teatro do estabelecimento era dirigido por J. Guimarães \& C., enquanto a Empresa Teatral de Variedades, de Ildefonso \& C., ficou responsável pelos outros divertimentos oferecidos. Vale citar que essa última era também proprietária do Teatro Mignon, um dos mais renomados e ativos da ocasião, onde foram apresentados espetáculos que tinham patinadores como $\operatorname{atração}{ }^{45}$.

\footnotetext{
42 Publicada quinzenalmente entre 1907 até 1911, segundo Chagas e Fernandes (2013), essa revista se utilizava do humor e da cultura de ilustração para tecer comentários sobre assuntos diversos.

43 Ver: VÁRIAS. Diário da Tarde, 16 out. 1906, p. 1.

${ }^{4}$ CLUBE Esportivo. Diário da Tarde, 21 mar. 1907, p. 1. Outra agremiação que estimulou a prática da modalidade foi o Paraná Esporte Clube (O ESPORTE entre nós. A República, 22 out. 1914, p. 2).

${ }^{45}$ MIGNON-Theatre. A República, 28 nov. 1914, p. 2. 


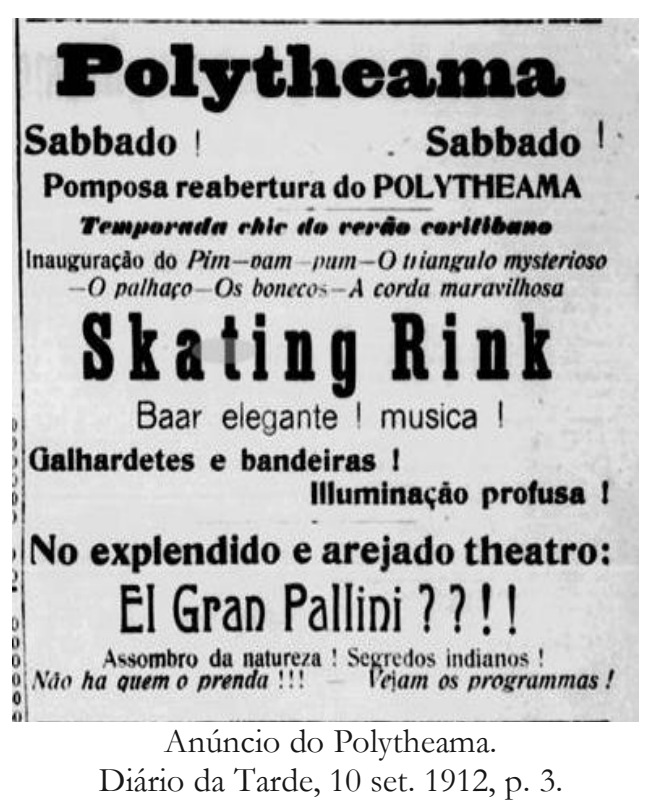

O Polytheama tomou uma decisão que parece ter levado em conta certas tensões que cercavam a modalidade: "De hoje em diante, o rink de patinação será frequentado somente pelas exmas.

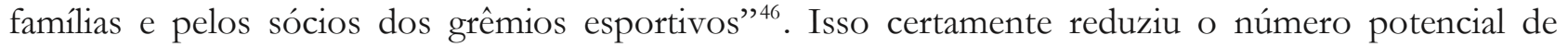
praticantes.

De outro lado, nas propostas de reforma do Passeio Público ${ }^{47}$ e da Praça Zacarias foram previstas a construção de rinques de patinação ${ }^{48}$. A modalidade integrava as preocupações de modernização do espaço urbano, a construção de logradouros que expressassem a ideia de civilização e o progresso que se desejava implementar.

À frente desses projetos se encontrava o prefeito Cândido de Abreu. O engenheiro, nos anos finais do século XIX, atuara no processo de construção de Belo Horizonte e tinha expectativa de implantar propostas urbanas semelhantes na capital paranaense. Assumiu diversos cargos, sempre marcando sua atuação pelas iniciativas de reformas do espaço público, inclusive na sua gestão da prefeitura $(1913 \text { a } 1916)^{49}$.

Em 1915, foi inaugurado um estabelecimento que deixou marcas na cidade, o primeiro centralmente dedicado à patinação, o Skating Rink, propriedade de Carvalho \& Nogueira e dirigido por Antonio Estevão de Carvalho, capitão da Guarda Nacional, importante comerciante da cidade ${ }^{50}$. Localizava-se na esquina da Rua Alegre (atual Dr. Cândido Leão) com a Rua da Assembleia (atual Dr. Muricy). Ao comentar a abertura do novo rinque, um cronista fez questão de observar que a "patinação é um esporte sempre em atualidade e bastante $c h i{ }^{2}{ }^{51}$.

Esperada com grande expectativa, a inauguração, contudo, foi desastrosa. A pista, apontada como uma das melhores e maiores do Brasil, apresentou problemas diversos e o estabelecimento teve que ser fechado ${ }^{52}$. Isso não reduziu o incentivo daqueles que celebravam iniciativas relacionadas ao

\footnotetext{
46 TEATROS e cinemas. A República, 24 set. 1912, p. 2.

47 O Passeio Público foi um dos primeiros e mais importantes espaços de lazer da cidade. Para mais informações, ver Galera (2014).

48 O PARQUE Municipal. A República, 30 jul. 1913, p. 1; MENSAGEM apresentada pelo sr. dr. Candido de Abreu, Prefeito Municipal. A República, 23 jul. 1915, p. 1.

49 Abreu tivera antes uma conturbada administração como prefeito (1892-1893). Para mais informações sobre esse importante personagem, ver Bencostta (2016).

${ }^{50}$ Vale citar que Carvalho e Nogueira também estavam envolvidos com o lucrativo negócio de erva-mate (A República, 20 out. 1917, p. 1).

${ }^{51}$ ESPORTIVAS. A República, 13 nov. 1915, p. 1.

52 SKATING-Rink. A República, 16 nov. 1915, p. 1.

Educação em Revista|Belo Horizonte |v.36|e235386|2020
} 
processo de modernização de Curitiba. A esperança, nas palavras de um cronista, era que o Skating Rink resolvesse "um grande problema no nosso meio social - o do ponto chic nos dias de semana" 53 .

Chic: esse passou a ser um termo corrente nos periódicos curitibanos, apresentado como uma postura que todos deveriam aprender. Perceba-se que, para o cronista, era um problema oferecer atividades de diversão pública somente nos fins de semana, um sinal de que a cidade ainda padecia com o marasmo e não assumira em definitivo uma feição moderna. A seus olhos, parecia necessário seguir oferecendo alternativas civilizadas para que os curitibanos definitivamente adquirissem novos comportamentos.

Reformado, efetivamente, o Skating Rink tornou-se um ponto de encontro da gente smart de Curitiba, na verdade frequentado por gente da elite, mas também por pessoas de menor poder aquisitivo. O preço, 1.000 réis por uma hora de patinação (com direito a empréstimo dos patins), de fato, era acessível para um bom estrato da população ${ }^{54}$. A título de comparação, uma garrafa de cerveja Atlantica Pilsen custava 6.500 réis, meia de gasosa (um refrigerante), 2.000 réis $^{55}$.

Esse sucesso motivou os proprietários a aperfeiçoarem o estabelecimento, melhorando a pista e construindo arquibancadas com cobertura ${ }^{56}$, no caso da capital paranaense, algo de grande importância em função da rigorosidade do $\operatorname{clima}^{57}$. De outro lado, uma vez mais, desencadearam-se preocupações no que tange à frequência. Para alguns cronistas, deveria haver limites para que não se ferissem os princípios civilizacionais da patinação.

Pressionados por algumas lideranças e cronistas, os proprietários do Skating-Rink tentaram estabelecer barreiras, começando por proibir o acesso de militares fardados de patente inferior. O debate pelos jornais foi amplo, boa parte sugerindo que se tratava de uma arbitrariedade. De sua parte, os empresários se defendiam dizendo que desejavam "fazer respeitada a moralidade naquele centro de diversões" ${ }^{58}$ para que as famílias tivessem certeza de que se tratava de um lugar seguro e civilizado.

A reação da imprensa não significou uma reivindicação de maior integração social. Para a maioria, todos deveriam ter acesso ao rinque, mas em momentos específicos. No olhar de um cronista: "Se a empresa quiser praticar justiça deve estabelecer turnos para a patinação, determinando horas para o exercício de moças, senhoras, cavalheiros, e do povo e inferiores" ${ }^{59}$. Chegou-se a decidir que os populares somente poderiam patinar após um determinado horário, sob o argumento de que se desejava preservar a moralidade do ambiente ${ }^{60}$.

A empresa obviamente resistia a tais indicações, especialmente por motivos financeiros. Se adotasse restrições de horários, a frequência poderia diminuir. Mais ainda, percebia que um dos atrativos do estabelecimento era exatamente o encontro de sexos na cena pública, algo que motivava muita gente a despeito das preocupações desencadeadas no que tange ao pudor.

Comparemos com o que ocorreu com o Internacional Futebol Clube, criado em 1912, reunindo importantes nomes da elite curitibana. Em 1915, construiu para seus sócios uma pista de patinação, iniciativa que não alcançava o grande conjunto da população, mas foi saudada como mais um sinal do avanço civilizacional de Curitiba ${ }^{61}$. Devemos lembrar que o ground da agremiação se localizava no mais distante bairro do Água Verde, onde vivia uma parte dos mais ricos.

\footnotetext{
53 ESPORTIVAS. A República, 25 nov. 1915, p. 2.

${ }^{54}$ Futuramente, quando houve maior número de rinques disputando o público, em dias de semanas, passou a se cobrar 500 réis para se patinar (ESPORTIVAS. A República, 27 jan. 1916, p. 2).

55 A Republica, 3 fev. 1915, p. 4.

56 SKATING-Rink. A República, 4 dez. 1915, p. 2.

${ }^{57}$ Em muitas ocasiões se anunciou que os espaços de patinação ficaram vazios em função do mau tempo. Ver, por exemplo: ESPORTIVAS. A República, 29 dez. 1915, p. 2.

58 O RINK. Diário da Tarde, 15 dez. 1913, p. 2.

${ }^{59}$ Diário da Tarde, 7 dez. 1915, p. 2.

${ }^{60}$ A República, 6 jan. 1916, p. 2.

${ }^{61}$ UM BELO exemplo. Diário da Tarde, 14 set. 1915, p. 2. Para mais informações sobre o Internacional, ver: Capraro (2002), Moletta Junior (2009) e Souza (2014). 


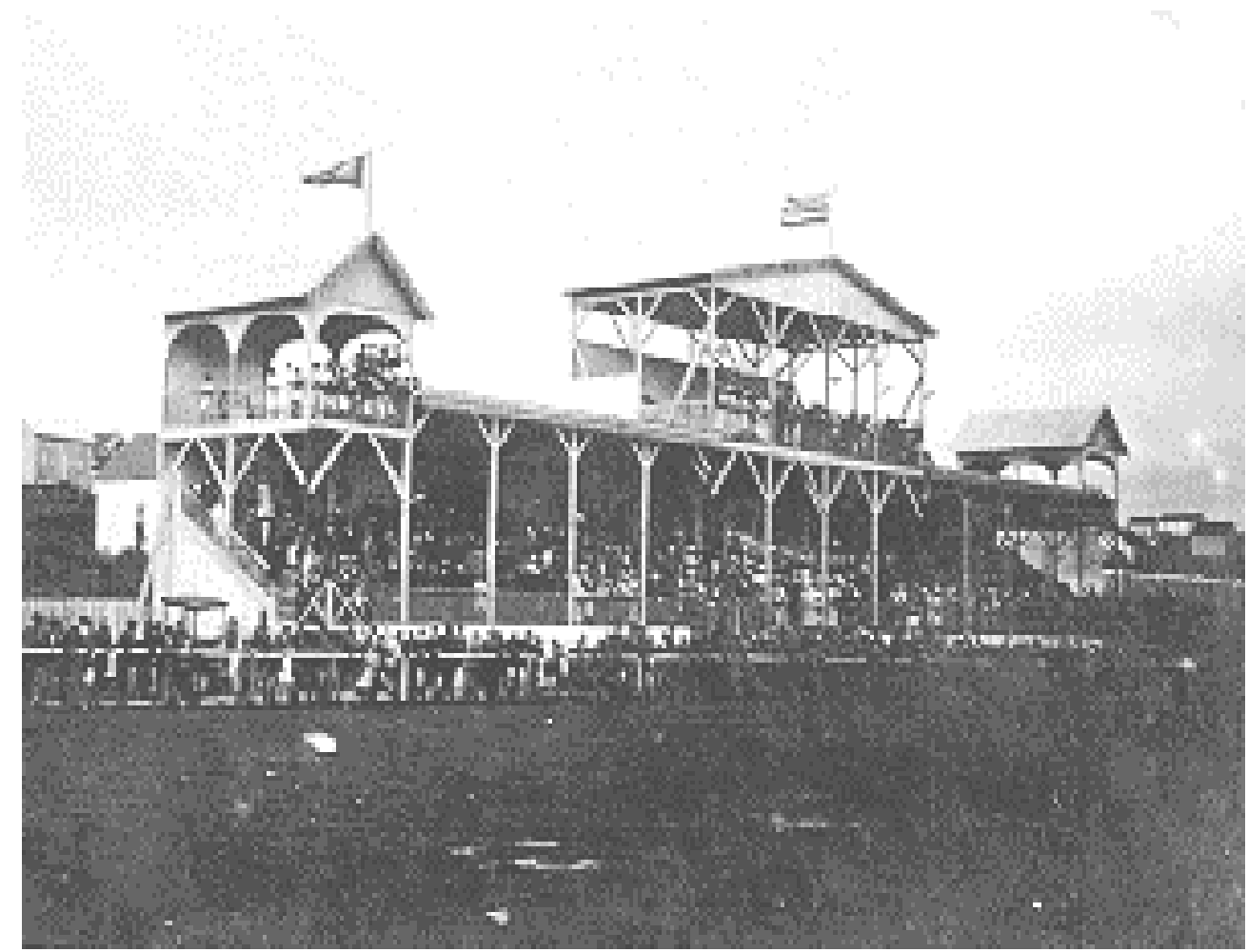

Campo do Internacional Futebol Clube (atual estádio do Clube Athlético Paranaense). Curitiba, bairro do Água Verde, 1915.

(CAPRARO, 2002).

Perceba-se como uma sessão de patinação do clube foi descrita por um cronista: gente da elite curitibana, convivendo em harmonia, patinando ao som de uma banda, tomando um "five o' clock tea". Segundo o informante, teria sido uma tarde perfeita se não fossem "elementos estranhos à sociedade que invadiram o recinto por um descuido da diretoria, não tendo postado porteiros nas entradas" ${ }^{62}$. Os festejos dessa agremiação, inclusive aqueles nos quais o skating era o destaque, foram usualmente elogiados pelos jornais por sua dinâmica mais restrita ${ }^{63}$.

No mesmo período, acirraram-se críticas ao Skating Rink. Para um leitor, Diogo Coutinho da Silveira, eram exagerados os elogios ao estabelecimento, jamais sendo ponto de encontro da elite, mas sim de gente, a seu ver, de pouco valor, "moços galantes, verdadeiros Don Juans que intitulando-se ótimos patinadores tomam as incautas senhoritas pelos braços, e de vez em quando (para não dizer constantemente) fazem escandalosas bolinagens". O autor dizia estar imbuído do espírito de "moralizar esse agradável esporte que se está, infelizmente, entre nós se transformando em grossa patuscada"64.

Esse debate explicita uma das ambiguidades usuais em sociedades que aderem a projetos de modernização. A ideia de uma cultura de massa é central, fundamental para a manutenção das iniciativas empresariais que dependem da venda de ingressos e outros produtos para se manter. Além disso, é importante no tocante a educar todos para que se ajustem aos novos comportamentos exigidos, na materialização cotidiana das próprias noções de civilização e progresso. Todavia, os mais ricos desejam seguir tendo espaços exclusivos, até mesmo porque nem sempre o grande conjunto da população se comporta como deles se espera nos discursos, o que desencadeia tensões, mas também um processo de circularidade cultural.

De toda forma, mesmo que cercada de algumas polêmicas, mas também muitos elogios, a patinação se espraiou em Curitiba. Um sinal interessante da difusão do hábito foi a gestação de um mercado ao seu redor, especialmente em relação à venda de patins, um produto que passou a ser mais

\footnotetext{
${ }^{62}$ FIVE o'clock tea. A República, 27 dez. 1915, p. 1.

${ }^{63}$ Ver, por exemplo: MOVIMENTO social. Diário da Tarde, 7 jan. 1916, p. 2.

${ }^{64}$ O RINK. Diário da Tarde, 7 dez. 1915, p. 2. 
encontrado nas melhores lojas da cidade, como a Casa Modelo, que tornou o artefato um atrativo constante em seus anúncios fartamente publicados nos jornais ${ }^{65}$.

A Casa Modelo participou ativamente das iniciativas da patinação. Um exemplo interessante é seu apoio ao concurso promovido por A República, mais um sinal do sucesso da prática: "Qual é o melhor patinador?" ${ }^{66}$. Para votar, os interessados enviavam um cupom publicado no jornal. A contenda contou com a participação de mais de 6.000 pessoas. O vencedor ganhou um par de patins do estabelecimento comercial.

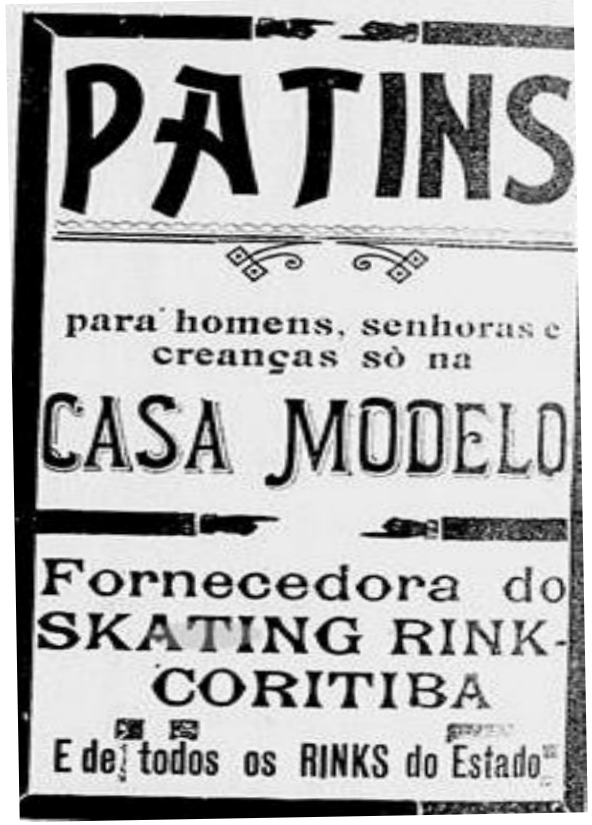

Anúncio de venda de patins, Casa Modelo. A República, 17 dez. 1915, p. 3.

$\mathrm{Na}$ verdade, foi uma vencedora. Sinal dos novos tempos em Curitiba. A escolhida pelo voto foi Edith Simas, que recebeu o prêmio com grande festa promovida no Skating Rink ${ }^{67}$. De fato, um aspecto progressivamente enfatizado nas propagandas foi a presença de patinadoras, em muitas ocasiões citadas nominalmente.

De um lado, era um sinal do aumento do protagonismo feminino. De outro, era também uma forma de garantir (ou ao menos tentar garantir) o aspecto familiar do divertimento. Além disso, tal partcipação era celebrada por se considerar que as mulheres também deveriam ser educadas para a nova dinâmica pública. Mais ainda, ampliava-se o público que pagava para patinar.

Esse concurso, do qual participou ativamente o Skating Rink, foi também uma estratégia desse estabelecimento para enfrentar a concorrência. Deve-se ter em conta que, àquela altura, a população de Curitiba aumentara muito. No censo de 1920, estimou-se quase 80.000 pessoas $^{68}$. De toda forma, ainda era uma cidade pequena, a oitava capital brasileira em número de habitantes. Não era um mercado consumidor tão grande para tantas iniciativas.

Em 1915, foi aberto um novo espaço dedicado à patinação, o Rink Park, localizado na Avenida Luiz Xavier, como de costume na região central da cidade. Dirigido por Moreira Garcez engenheiro, empreendedor, empresário e futuro prefeito (1920-1928 e 1938-1940), um dos líderes de

\footnotetext{
${ }^{65}$ Interessante observar que também surgiram nos jornais anúncios de serviços especializados no conserto de patins, mais um indício de que o uso do artefato se difundira pela cidade (Diário da Tarde, 24 fev. 1919, p. 1).

${ }^{66}$ SKATING-Rink. A República, 6 jan. 1916, p. 2.

${ }^{67}$ SKATING-Rink. A República, 9 fev. 1916, p. 2. O cronista estimou que participaram da festa cerca de 800 pessoas, entre as quais 72 que patinaram.

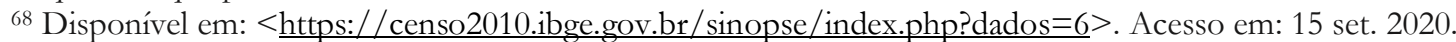


reformas urbanas e modernização de Curitiba -, era um complexo de entretenimentos, com bar, cinema e parque, entre outras diversões ${ }^{69}$.

Em 1916, na mesma rua, foi inaugurado o Palace Theatre, muito elogiado pela qualidade da pista de patinação e das instalações que, segundo um cronista, acolhia até 1800 pessoas ${ }^{70}$. Por ser coberto, poderia ser mais utilizado nos dias de mau tempo.

Desde o início, embora aberto ao grande público, estabeleceu-se um controle de entrada, somente permitida a famílias e cavalheiros. Por tais características, o estabelecimento contou com certa simpatia do poder público ${ }^{71}$ e foi utilizado por outras agremiações para promover suas festas, algumas das quais também tendo a patinação como atração, como foi o caso do Grêmio Bouquet ${ }^{72}$, uma agremiação feminina de elite que se dedicava a reuniões sociais e atividades filantrópicas (AVANZINI, 2011).

No mesmo ano, no Parque Progresso, situado na Rua Ivahy (atual Getúlio Vargas), outro rinque foi aberto ao público ${ }^{73}$. Já o Royal Skating, pequeno estabelecimento localizado na Rua Alegre, como novidade ofereceu uma gratuita escola de patinação para mulheres ${ }^{74}$. Da mesma forma, com boa infraestrutura, foi inaugurado o Skating Rio Branco, instalado na Rua 15 de novembro ${ }^{75}$.

Assim sendo, Curitiba chegou a ter seis rinques de patinação simultaneamente abertos ao público $^{76}$, em muitas ocasiões lotados, mesmo em dias de semana, promovendo sessões constantes da prática, bem como festas diversas (como bailes). Além desses, havia o rinque privado do Internacional Futebol Clube. Inegavelmente, o skating tornara-se uma diversão de sucesso na capital paranaense naqueles meados da década de 1910.

\section{O que significa patinar?}

O dia de ontem amanheceu lindíssimo. Céu azul e lindo. Temperatura bem quente desde cedo. E a tarde veio encantadora...Crepúsculo suave, mas um tanto triste. A essa hora, tensamente, parecia vir uma nascente que se nublaria em intensa chuva. Felizmente, a chuva falhou e a noite foi estrelada e bastante fresca. Pela cidade alegre foi grande o movimento. Os cinemas e o rink, e as ruas, estiveram repletas, e quando começou a volver o silêncio noturno sobre a cidade, já era tarde... ${ }^{77}$

Como vimos, a patinação foi uma das diversões preferidas na cidade de Curitiba na década de 1910, uma experiência que começara nos anos finais do século XIX e veio se estruturando pari passu com a melhor conformação de um mercado de entretenimentos. Vários foram os debates ao seu redor. Nesse período, que representações foram forjadas acerca da prática? A documentação apresentou limites para a análise/interpretação dos discursos, mas, ainda assim, pela dinâmica de funcionamento dos rinques e breves opiniões publicadas nos jornais, foi possível traçar algumas percepções.

No que tange às primeiras experiências, promovidas no século XIX, não foi possível identificar discursos sobre a prática. Todavia, destaca-se que integraram as alternativas de entretenimento que estavam se conformando, oferecidas por estabelecimentos que apresentavam à cidade uma nova dinâmica social, uma vida pública mais ativa, nos quais estava se aprendendo a "ser moderno". Tratavase de mais uma novidade, já usual em outras capitais, que se estruturava numa Curitiba que crescia e passava por mudanças.

\footnotetext{
${ }^{69}$ Diário da Tarde, 30 dez. 1915, p. 1.

${ }^{70}$ PALACE Theatre. A República, 6 jun. 1916, p. 1.

${ }^{71}$ Não surpreende que, em sua inauguração, marcasse presença o presidente do Estado, Afonso de Camargo (PALACE

Theatre e sua inauguração. A República, 3 jul. 1916, p. 1).

72 GREMIO Bouquet. A República, 16 set. 1916, p. 2.

73 TEATROS e diversões. Diário da tarde, 25 de jan. 1916, p. 2.

${ }^{74}$ ESPORTIVAS. A República, 4 fev. 1916, p. 2.

75 SKATING Rio Branco. Diário da Tarde, 27 jan. 1916, p. 2.

${ }^{76}$ Havia mais um skating rink em construção na Rua Voluntários da Pátria. Esse, contudo, não chegou a abrir em função de um acidente com vítimas (DESASTRE. Parede que desaba. Cinco pessoas feridas. A República, 9 mar. 1916, p. 2).

77 CURITIBA social. A República, 7 jan. 1916, p. 2. 
Há que se destacar, ainda no século XIX, a presença da patinação numa escola que se pretendia sintonizada com os novos tempos, por isso valorizadora da educação física. Nessa experiência, a prática se aproximou das ideias de saúde e higiene, integrando estratégias educacionais consideradas adequadas para a juventude.

O diretor José Cupertino dialogava com discursos pedagógicos e médico-higienistas oriundos do continente europeu (SOARES, 2004; GONDRA, 2004), bem como tinha em conta a possibilidade de mobilizar práticas que gozavam de alguma repercussão no mercado de entretenimentos, vivenciadas na dinâmica dos espetáculos, "portadora de uma força simbólica capaz de fazer convergirem determinados valores, estruturas narrativas e experiências estéticas” (MELO; PERES, 2016, p. 1141).

Vejamos que, em alguns elogios ao Colégio São José, a utilização da patinação foi tratada como possibilidade de articular o entretenimento com preocupações com a saúde: "Além de bons aparelhos destinados à educação física, estas ainda divertem-se com patinações, tiro ao alvo, exercícios militares etc" ${ }^{\text {78 }}$.

Nos anos iniciais do século XX, o incentivo da prática da patinação pelo Sport-Club enfatizou a ideia de que poderia contribuir com a difusão de hábitos de saúde e higiene, em contraponto a certos divertimentos considerados perniciosos num momento em que houve grande expansão da vida pública. Para um cronista, a agremiação oferecia "elegantes diversões e úteis torneios de força, destreza e agilidade, bem diversos dos entretenimentos anti-higiênicos e atrofiantes generalizados nesta capital" ${ }^{79}$. Vale observar que a sociedade esportiva sempre enfatizou discursos de modernidade, a intenção de contribuir com o progresso e processo civilizatório da capital paranaense,

a prática dos exercícios físicos baseados nos preceitos higiênicos como o 'sentimento da sociedade moderna', alçando os fundadores da agremiação à condição de intérpretes da modernidade, espécie de vanguarda, capaz de capturar o "espírito do tempo" convertendo-o em prática (SOUZA, 2014, p. 41).

A patinação, para além do aspecto de diversão, era mobilizada como uma ferramenta educacional. Comentando um festival esportivo organizado pelo Sport-Club, um cronista bem registrou certas representações que cercavam a prática de esportes, entre os quais a modalidade dos patins:

$\mathrm{Na}$ cancha muito alva, a mocidade masculina entregue aos rudes jogos do esporte punha à prova a agilidade e a rijeza muscular, oferecendo o espetáculo tão comum nas remotas eras em que os moços, sem descurar do aperfeiçoamento intelectual, desenvolviam nos torneios da antiguidade as forças físicas, fazendo surgir a raça forte e viril $(. . .)^{80}$.

As representações se tornaram mais diversas quando logrou sucesso o rinque do Coliseu. O estabelecimento era apresentado como uma iniciativa que contribuía para a modernização de Curitiba. Todavia, estava mais ligado ao agenciamento direto do espetáculo do que aos discursos educacionais propugnados por clubes e escolas. Isso não significa que foi menor o contributo do espaço para o intuito de adequação dos indivíduos à dinâmica pública: tinha-se que aprender a frequentar o local, inclusive pelo intenso compartilhamento com o sexo oposto; poder-se-ia aprender a patinar, seja contando com a ajuda de alguém ou com professores que foram oferecidos pela empresa.

Ao redor do Coliseu, explicitaram-se tensões na representação de que a patinação, por ser uma prática moderna, adequada aos novos tempos, deveria ser o contraponto de atividades tidas como ultrapassadas. Isso se acentuava quando se contrastava com espaços nos quais a modalidade era estimulada com base em parâmetros distintos, como no caso do Clube Esportivo, no qual se defendia que "sem a agilidade do corpo que dá graça, sem o exercício dos músculos que dá a força, como poderá o espírito triunfar na vida, se não miserável e deploravelmente?"

\footnotetext{
${ }^{78}$ COLÉGIO S. José. A Tribuna, 10 dez. 1895, p. 2.

${ }^{79}$ SPORT-Club. A República, 28 nov. 1904, p. 2.

80 SPORT-Club. A República, 11 dez. 1904, p. 2.

${ }^{81}$ CLUBE Esportivo. Diário da Tarde, 21 mar. 1907, p. 1.

Educação em Revista|Belo Horizonte|v.36|e235386|2020
} 
Com o Skating Rink, percebe-se a busca de articulação de distintas representações. Para um cronista, "como em todas as capitais, além de ser um ponto de cultura física, é também um lugar agradável de reunião seleta e de palestra amiga e boa, contribuindo bastante para o estreitamento das relações sociais" $"$. Muitos saudaram o estabelecimento que, a seu ver, poderia se constituir em oportunidade para que se desenvolvessem comportamentos chics, para que se aprendesse a se portar na cena pública: "nosso set quase todo converge para lá, onde passa horas agradáveis e risonhas, apreciando a elegância dos sportmen exímios e as desordenadas quedas incessantes dos novatos" $\$ 33$.

Num cenário em que se enfatizavam propostas de modernização da sociedade curitibana, o sportman - e a seu tempo a sportwoman - se constituía em um modelo a ser seguido: a valorização da exposição pública, desde que acompanhada de limites no comportamento, mais distendidos, mas ainda assim com certas formalidades. Era a figura do empreendedor que, na cena urbana, demonstrava suas qualidades superiores e disposição de conduzir o país a um alvissareiro futuro.

Mesmo celebrando os avanços promovidos pelo Skating Rink, a imprensa constantemente cobrou da empresa responsável tanto "a maior seleção possível dos frequentadores" função da presença feminina, quanto "a organização de um regulamento a fim de melhor regularizar as diversões, bem como evitar possíveis reclamações". Essa preocupação se tornou notável no caso do Palace Theatre que, desde o início, pretendeu-se mais restrito a determinados setores sociais. O estabelecimento tinha uma certa pretensão de exaltar o progresso da cidade, algo expresso na qualidade de suas instalações.

Trata-se de um traço típico de sociedades que aderem ao ideário e imaginário da modernidade: ajustar excitabilidade e controle, devendo todos ser educados para a adoção de comportamentos que não maculem a ordem pública. Como vimos, as decisões no sentido de restringir o acesso ocasionaram polêmicas de ordem distinta. A questão sempre foi: como equacionar os limites do uso do espaço urbano ${ }^{85}$

Por isso, um cronista se mostrou indignado quando comentou que frequentadores do Skating Rink estavam vaiando alguns patinadores. Para ele, rinque não era um "circo de cavalinhos" e o povo deveria aprender a se comportar, não reproduzindo procedimentos que foram usuais em outros tempos, em espaços, a seu ver, menos civilizados ${ }^{86}$. Perceba-se a dimensão educacional que cercava os estabelecimentos de entretenimento, a indução para adoção de posturas polidas e comedidas, uma exigência nem sempre observável, o que apontava os limites dos discursos civilizacionais, mas de toda forma pressionava os indivíduos.

Vejamos que, por ocasião da decisão do Internacional Futebol Clube de construir um rinque, um cronista a saudou como sinal de que aumentara a preocupação da agremiação com a educação da juventude: "a par do desporto violento coloquem aos intrépidos rapazes os jogos delicados, que treinam o corpo sem o expor às surpresas perigosas dos tombos e cabeçadas" ". Obviamente, nessa consideração ideal, não se tinha em conta que também eram comuns as quedas no esporte dos patins. A questão em tela era mesmo a consideração de que a patinação se tratava de uma prática chic e mais controlada, menos afeita aos "exageros" do futebol ${ }^{88}$.

O velho esporte bretão, por ter rapidamente se popularizado e por sua dinâmica, talvez seja o que melhor dramatizava essas tensões urbanas. Esse tema foge ao escopo de nosso estudo, mas serve como contraponto. A ideia generalizada defendida, no fundo, era de que, se a patinação era considerada superior do ponto de vista civilizacional, não poderia ao seu redor repetir certos procedimentos mais afeitos à turba.

\footnotetext{
82 ESPORTIVAS. A República, 13 nov. 1915, p. 1.

${ }^{83}$ ESPORTIVAS. A República, 25 nov. 1915, p. 2.

${ }^{84}$ SKATING-Rink. A República, 4 dez. 1915, p. 2.

${ }^{85}$ Gruner (2012) trata desse tema abordando as preocupações com o avanço do cinema na Curitiba das primeiras décadas do $\mathrm{XX}$.

${ }^{86}$ ESPORTIVAS. A República, 18 jan. 1916, p. 1.

${ }^{87}$ UM BELO exemplo. Diário da Tarde, 14 set. 1915, p. 2.

88 Sobre as tensões desencadeadas pelo futebol na sociedade curitibana de início de século, ver: Capraro (2002), Moleta Junior (2009) e Souza (2014).
} 
Enfim, a patinação foi representada como um contributo para a educação dos envolvidos, ainda que esses nem sempre seguissem esses ditames ou estivessem preocupados com tal dimensão. Era mesmo mais uma diversão que se apresentava numa cidade em mudança. E se constituiu numa experiência que deixou marcas na urbanidade curitibana daquele princípio de século.

\section{CONSIDERAÇÕES FINAIS}

Em Curitiba, desde as primeiras experiências, a patinação se articulou com movimentos de adesão ao ideário e imaginário da modernidade, modificando-se, contudo, no decorrer do tempo, a natureza e ênfase dos discursos ao seu redor. Entre o eminente agenciamento do espetáculo e as propostas explícitas de relação com noções de saúde e higiene, forjaram-se representações sobre sua utilidade como indutora da adoção de novos comportamentos considerados adequados numa sociedade em mudança, a aquisição de posturas chics.

As experiências ao seu redor dramatizaram ambiguidades típicas da modernidade, tanto a necessidade de garantir acesso ao maior número de interessados sem perder de vista a questão da exclusividade, quanto as tensões entre excitabilidade e controle, ambas relacionadas aos novos usos do espaço urbano, ao estabelecimento de limites para as vivências sociais. Esse processo de negociações ficava claro no que tange à participação feminina, uma preocupação constante, ainda que também ocorrência celebrada e considerada importante.

Dessa maneira, a patinação, diversão que conquistou a população curitibana naqueles meados dos anos 1910, foi mobilizada como uma estratégia de educação do público e dos praticantes, concebida como uma intervenção corporal de dupla ordem, aquisição de determinados comportamentos, mas também aprendizado de novas técnicas corporais.

\section{REFERÊNCIAS}

AVANZINI, Claudinéia Maria Vischi. As origens do Hospital de Crianças. Saúde e Educação em Curitiba, 1917-1932. Dissertação (Mestrado em Educação). Curitiba: Universidade Federal do Paraná, 2011.

BENCOSTTA, Marcus Levy. Cândido de Abreu: projetos do primeiro urbanista da cidade de Curitiba do início do século XX. Revista Brasileira de História, São Paulo, v. 36, n. 73, p. 231-254, dez. 2016.

BENVENUTTI, Alexandre Fabiano. As reclamações do povo na Belle Époque: a cidade em discussão na imprensa curitibana (1909-1916). Dissertação (Mestrado em História). Curitiba: Universidade Federal do Paraná, 2004.

BERTUCCI, Liane Maria. Saúde pública na capital paranaense: dos "bons ares" à febre tifoide. In: ANPUH. Anais do XXVI Simpósio Nacional da ANPUH - Associação Nacional de História. São Paulo: ANPUH-SP, 2011. p. 1-12.

BRANDÃO, Angela. A fábrica de ilusões: o espetáculo das máquinas num parque de diversões e a modernização de Curitiba (1905-1913). Curitiba: Prefeitura Municipal de Curitiba/ Fundação Cultural de Curitiba, 1994.

BRANDÃO, Leonardo. Histórias esquecidas do esporte. Conexões: Educação Física, Esporte e Saúde, Campinas, v. 7, n. 2, p. 13-23, 2009.

CAMPOS, Nevio de. Diário da Tarde e Cruzeiro: querelas entre anticlericais e católicos no Paraná (19311932). Antíteses, Londrina, v. 6, n. 12, p. 391-416, 2013. 
CANCLINI, Néstor García. Culturas híbridas: estratégias para entrar e sair da modernidade. São Paulo: Edusp, 1997.

CAPRARO, André Mendes. Football, uma prática elitista e civilizadora: investigando o ambiente social e esportivo paranaense do início do século XX. Dissertação (Mestrado em História). Curitiba: Universidade Federal do Paraná, 2002.

CHAGAS, Luãn José, Vaz; FERNANDES, Marcio. A Modernidade em O olho da Rua: apontamentos sobre a cultura do visual na Curitiba do começo do século 20. In: UFOP. $9^{\circ}$ Encontro Nacional de História da Mídia. Ouro Preto: Alcar, 2013.

COLATUSSO, Denise Eurich. Imigrantes alemães na hierarquia de status da sociedade lusobrasileira (Curitiba, 1869 a 1889). Dissertação (Mestrado em História). Curitiba: Universidade Federal do Paraná, 2004.

CRARY, Jonathan. A visão que se desprende: Manet e o observador atento no fim do século XIX. In: CHARNEY, Leo; SCHWARTZ, Vanessa (orgs.). O cinema e a invenção da vida moderna. São Paulo: Cosac \& Naify, 2001. p. 81-114.

CORRÊA, Amélia Siegel. Imprensa política e pensamento republicano no Paraná no final do XIX. Revista de Sociologia e Política, Curitiba, v. 17, n. 32, p. 139-158, 2009.

GALERA, Izabella. Os parques do século XIX em meio a cidade contemporânea: um estudo comparativo entre o Passeio Público de Curitiba e o Parque Municipal de Belo Horizonte. Dissertação (Mestrado em Ambiente Construído e Patrimônio Sustentável). Belo Horizonte: Universidade Federal de Minas Gerais, 2014.

GILLER, Marilia. O jazz no Paraná entre 1920 e 1940: um estudo da obra O Sabiá, fox trot shimmy de José da Cruz. Dissertação (Mestrado em Música). Curitiba: Universidade Federal do Paraná, 2013.

GOMES, Leonardo do Couto. “Malum non admite”: A cultura física no Clube Curitibano (1881-1914). Dissertação (Mestrado em Educação Física). Curitiba: Universidade Federal do Paraná 2019.

GONDRA, José Gonçalves. Artes de civilizar: medicina, higiene e educação escolar na Corte Imperial. Rio de Janeiro: EdUERJ, 2004.

GRUNER, Clóvis. Paixões torpes, ambições sórdidas: transgressão, controle social, cultura e sensibilidade moderna em Curitiba, fins do século XIX e início do XX. Tese de Doutorado. Tese (Doutorado em História). Curitiba: Universidade Federal do Paraná, 2012.

GUNNING, Tom. O retrato do corpo humano: a fotografia, os detetives e os primórdios do cinema. In: CHARNEY, Leo; SCHWARTZ, Vanessa (orgs.). O cinema e a invenção da vida moderna. São Paulo: Cosac \& Naify Edições, 2001. p. 39-80.

LACERDA, Cassiana Lícia de. 1894 - Curitiba oblíqua e dissimulada em tempos de revolução. Revista Ideias, Curitiba, 2014.

LUCA, Tânia Regina. História dos, nos e por meio dos periódicos. In: PINSKY, Carla B. (org.). Fontes históricas. São Paulo: Ed. Contexto, 2005. p. 111-153. 
MAIA, João Marcelo E. Costa Pinto em dois tempos: os efeitos periféricos na circulação de ideias. Tempo Social, São Paulo, v. 31, n. 2, p. 173-198, 2019.

MARTINS, William de Souza Nunes. Paschoal Segreto: ministro das diversões do Rio de Janeiro 1883 - 1920. Dissertação 9Mestrado em História Social). Rio de Janeiro: Universidade Federal do Rio de Janeiro, 2004.

MELO, Victor Andrade de. Uma diversão civilizada: a patinação no Rio de Janeiro do século XIX (18721892). Locus, Juiz de Fora, v. 23, n. 1, 2017.

MELO, Victor Andrade de. Saudável e fashionable: a patinação no Rio de Janeiro do século XIX (18781892). Revista Brasileira de Ciências do Esporte, Florianópolis, v. 40, n. 1, p. 17-23, 2018.

MELO, Victor Andrade de. O espetáculo que educa o corpo: clubes atléticos na cidade de Niterói dos anos 1880. História da Educação, Pelotas, v. 23, e85836, p. 1-34, 2019.

MELO, Victor Andrade de. Educação, civilização, entretenimento: o Tivoli - um parque de diversão no Rio de Janeiro do século XIX (1846-1848). Revista Brasileira de História da Educação, Maringá, 2020 .

MELO, Victor Andrade de; KARLS, Cleber Eduardo. A modernidade sobre rodinhas: a patinação na Porto Alegre do século XIX (1878-1882). História Unisinos, São Leopoldo, v. 20, n. 1, p. 50-59, 2016.

MELO, Victor Andrade; KARLS, Thaina Schwan. Novas dinâmicas de lazer: as fábricas de cerveja no Rio de Janeiro do século XIX (1856-1884). Movimento, Porto Alegre, v. 24, n. 1, p. 147-160, mar. 2018.

MELO, Victor Andrade de; SANTOS, Flavia Cruz. Deslizando rumo ao progresso: a patinação em São Paulo (1877-1912). Movimento, Porto Alegre, v. 23, n. 1, p. 171-184, 2017.

MELO, Victor Andrade de; PERES, Fabio de Faria. Relações entre ginástica e saúde no Rio de Janeiro do século XIX: reflexões a partir do caso do Colégio Ab́lio, 1872-1888. História, ciência e saúde Manguinhos, Rio de Janeiro, v. 23, n. 4, p. 1133-1151, dez. 2016.

MOLETTA JUNIOR, Celso Luiz. Futebol e formação do espaço público no contexto da fundação do Coritiba Football Club (Curitiba, 1900-1915). Dissertação (Mestrado em História). Curitiba: Universidade Federal do Paraná, 2009.

MORAES, Julio Lucchesi. O Magnata de Valência: capitalistas, bicheiros e comerciantes do Primeiro Cinema no Brasil (1904-1921). Revista Movimento, São Paulo, n. 1, p. 1-18, 2012.

MORAES E SILVA, Marcelo Moraes. Novos modos de olhar outras maneiras de se comportar: a emergência do dispositivo esportivo da cidade de Curitiba (1899-1918). Tese (Doutorado em Educação). Campinas: Universidade Estadual de Campinas, 2011.

MYSKIW, Antonio Marcos. Curitiba, "República das letras" (1870/1920). Revista Eletrônica História em Reflexão, Dourados, v. 2, n. 3, p. 1-27, 2008.

PEREIRA, Magnus Roberto de Mello. Semeando iras rumo ao progresso: ordenamento jurídico e econômico da sociedade paranaense, 1829-1889. Curitiba: Editora da UFPR, 1996.

PEZZOLE, Dino Ricardo. Jornal Dezenove de Dezembro. Monografia (Graduação em Design). Curitiba: Universidade Tuiuti do Parana, 2006. 
PILOTTO, Osvaldo. Cem anos de imprensa no Paraná [1854-1954]. Curitiba: Instituto Histórico, Geográfico e Etnográfico Paranaense, 1976.

PORTER, Roy. Os ingleses e o lazer. In: CORBIN, Alain (org.). História dos tempos livres. Lisboa: Teorema, 2001. p. 19-58.

PRIORI, Claudia. Mulheres e a pintura paranaense: relação entre arte e gênero (fim do século XIX e começo do século XX). História: Questões \& Debates, Curitiba, v. 65, n. 1, p. 359-384, 2017.

SANTOS, Antonio Cesar de Almeida. Ideário do progresso e cidades: uma Curitiba das primeiras décadas do século XX. Estudos Ibero-Americanos, Porto Alegre, v. 24, n. 1, p. 75-94, 1998.

SÊGA, Rafael Augustus. Maragatos dos Campos Gerais: razões que levam alguns setores da sociedade paranaense a aderir à Revolução Federalista. Revista Tecnologia e Humanismo, Curitiba, v. 15, n. 20, p. 71-80, 2001.

SILVA, José Cláudio Sooma. Teatros da Modernidade: representações de cidade e escola primária no Rio de Janeiro e em Buenos Aires nos anos 1920. Tese (Doutorado em Educação). Rio de Janeiro: Universidade do Estado do Rio de Janeiro, 2009.

SOARES, Carmem Lúcia. Educação física: raízes europeias e Brasil. Campinas: Autores Associados, 2004.

SOARES, Luiz Carlos. A Albion revisitada. Rio de Janeiro: 7 Letras/Faperj, 2007.

SOUZA, Jhonatan Uewerton. O jogo das tensões: clubes de imigrantes italianos no processo de popularização do futebol em Curitiba (1914-1933). Dissertação (Mestrado em História). Curitiba: Universidade Federal do Paraná, 2014.

TRINDADE, Etelvina. Cidade moderna e espaços femininos. Projeto História, São Paulo, n. 13, p. 109-120, jun. 1996.

VANALI, Ana Crhistina. Apontamentos dos registros cinematográficos referentes ao Contestado. Revista NEP (Núcleo de Estudos Paranaenses-UFPR), Curitiba, v. 3, n. 2, p. 61-77, jun. 2017,

VIACAVA, Vanessa Maria Rodrigues. "Em busca de Curitiba perdida": a construção do habitus curitibano. In: UFPR. XII Simpósio Internacional Processo Civilizador, Civilização e Contemporaneidade. Recife, UFPR, 2009.

ZATTTI, Carlos. O Paraná e o Paranismo. Curitiba: Clube de Autores, 2010.

Submetido: $21 / 03 / 2020$

Aprovado: $11 / 06 / 2020$ 